\title{
THE CHALLENGES IN HIGHER EDUCATION INSTITUTIONS IN INDONESIA: ARE WE ENTREPRENEURIAL UNIVERSITY YET?
}

\author{
Eko Sakapurnama, Martani Huseini, Pantius D Soeling \\ Department of Business Administration, \\ Faculty of Administrative Science Universitas Indonesia
}

\begin{abstract}
Today, the world has entered the industry revolution 4.0 era. It is inevitable that higher education institutions become the agents of change of civilizations that support the phenomenon. Some conceptions related to knowledgebased economy, entrepreneurial university or third-generation university, became the frame of thinking of experts who encourage university policies and strategies. This literature review is intended as an analysis on the current condition of higher education institutions in Indonesia, especially Universitas Indonesia and Universitas Gajah Mada, both of which are leading universities in Indonesia. As a state-owned university that is given an autonomy, the government restricts their subsidy, and this has put both state-owned universities (PTNBH) in a dilemma in an attempt to implement their Tri Dharma's activities, mainly because unclear policy to get the financial income from non-educational costs. This article will highlight some thoughts related to entrepreneurial universities, such as definitions, transformation models, and challenges to become entrepreneurial universities.
\end{abstract}

Keywords: Higher Education Institution, Knowledge Based Economy, Entrepreneurial University, Entrepreneurshipv 


\section{INTRODUCTION}

It has become a fact that universities as the center of knowledge often create various innovations and hence are considered as an agent that changes a country's civilization (Philpott, et. al, 2011; Fayolle and Redford, 2014). Universities are considered as the engine of development; an agent that contributes to the development process of a country (OECD, 2009). Several research results indicate that in the past twenty years, the global environment has been undergoing changes with regard to the roles of university, including its role as the knowledge-based economy (Etkowitz, 2004; Sporn, 2001). Powell and Snellman (2004) suggested that knowledge-based economy can be perceived as the production and service process that is based upon intensive scientific activities in creating both technical and scientific advantages. The key component of a knowledgebased economy is higher dependency on intellectual ability as compared to physical or natural resources inputs.

The development of knowledgebased economy has placed knowledge as the main source of advantage or competitiveness and growth of a nation's economy, and university becomes a central institution that directly moves and initiates the economic growth of a country in the future (Mohrman, Ma, Baker, 2008; Etzkowitz, 2004; Huggins, John, and Upton, 2008; OECD, 2009). The knowledge created by universities becomes one of the intangible resources for organizations which will in turn push toward sustainable advantage (Grant, 1996).

The above phenomenon has put university under unprecedented challenge with regard to its goals, roles, organization, and scope within the society and economy. The information and communication technology revolution, emergence of knowledge economy, economic turmoil and funding condition have brought about new demands in the higher education system all around the world (OECD, 2009; McCaffery, 2004). Today, universities are facing higher uncertainty and complexity in their respective environment, as well as higher pressure for entrepreneurship from within the institution (Coyle, Gibb, Haskin, 2013). McCaffery (2004) argued that changes and very dynamic environment have forced universities to adapt with their environment.

Various challenges that arise in the universities' institution have become a research focus of several prominent international researchers. The challenges include the need for universities' institution to change their organizational strategy to address the dynamic challenge of competition in globalization era (De Zilwa, 2005), and financing barrier due to reduction of subsidy from the government, just like the one that happened in universities in the UK(Coyle, Gibb, Haskin, 2014; Gibb and Haskins, 2013). In addition, other challenges are related to the shift of national economic leverage component, from the previously natural resources into more knowledgebased economy, in which productivity and growth will become more dependent on knowledge (Dahlman, Aubert, 2001; Etzkowitz, 2004; Mohrman and Baker, 2008; Chen and Dahlman, 2004), as well as the development of free open contentbased learning method, a.k.a. Massive Open Online Courses (MOOC), which might reduce the number of conventional students, which will lead to decrease of universities' income.

This dynamic change in external environmental context has forced universities to develop entrepreneurial orientation (entrepreneurial university) Etkowitz, 2003; Philpott, et.al, 2011; Coyle, Gibb, Haskin, 2013; Gibb 
and Haskins, 2013). Fayolle and Redford (2014) argued that nowadays, universities need to develop more entrepreneurial orientation, change their strategy, structure, and practice, as well as culture, and assist students and faculty members to develop their entrepreneurial mindset and action. However, a challenge needs to be tackled, which is the fact that universities are a professional bureaucracy which core missions and values are associated with education and research. As consequence, their ability/capacity to change and adopt new behavior is rather challenged. This has created a paradox and resistance between what universities have to do to address the trend of world evolution and complexity.

Another aspect that is also a pushing factor for universities' change, from the previously focused on pure science development, is the reduction of government subsidy for higher education, which forces universities to seek other funding, such as what happens in the US and UK (Lyall and Sell, 2006; Gibb and Haskins, 2013). As consequence, "commercialization" of higher education arises, in which state (public) universities are transformed into private universities (Lyall and Sell, 2006).

Some scholars attempt to seek the appropriate institutional format of higher education that can match with the current condition. Etkowitz (1998), Klofsten and Jones-Evans (2000), Delanty (2000), and Coyle, Gibb, Haskin (2013), suggested that universities that are oriented to entrepreneurship (entrepreneurial universityy) are considered as the type of university that can address today and future challenges and phenomena. Universities do not only produce competent graduates and inventions from laboratory test, but also ensure that the knowledge resource can directly contribute to the economic growth of a country. Klofsten and JonesEvans (2000) and Delanty (2000) argued that universities are expected to play active roles by having entrepreneurship units that engage directly with the society (business-to-customers) as well as with other business actors (businessto-business).

Wissema (2009) explained that currently, the phenomenon of transition of higher education institutions have stepped onto its third generation, a.k.a. 3GU (Third-Generation University). In his book, he suggested that there are 3 (three) phases of development of university (see image 2.1.), which started from the first generation university (The Medieval University; which are Latinbased schools which produced great philosophers like Plato and Aristotle). Universities were not truly established in that era, though. According to Wissema (2009), universities were established for the first time when the church granted authority to anyone who intends to teach and any youth who intends to study, which led to the birth of the term "studium" or school.

"The universities were not established at a stroke. They emerged step by

step, 'by a concurrence of able men who had something they wished to

teach and youths who desired to learn'. Such an 'able man' would attract

other doctors who, in turn, would attract students and in this way a studium (school) was founded"

(Wissema, 2009, page 5-6).

Afterwards, still according to Wissema (200), the term "studium generale", which means "groups of schools", became the embryo of university, which literally means "totality" or "entirety", which combined various school groups/ associations. 


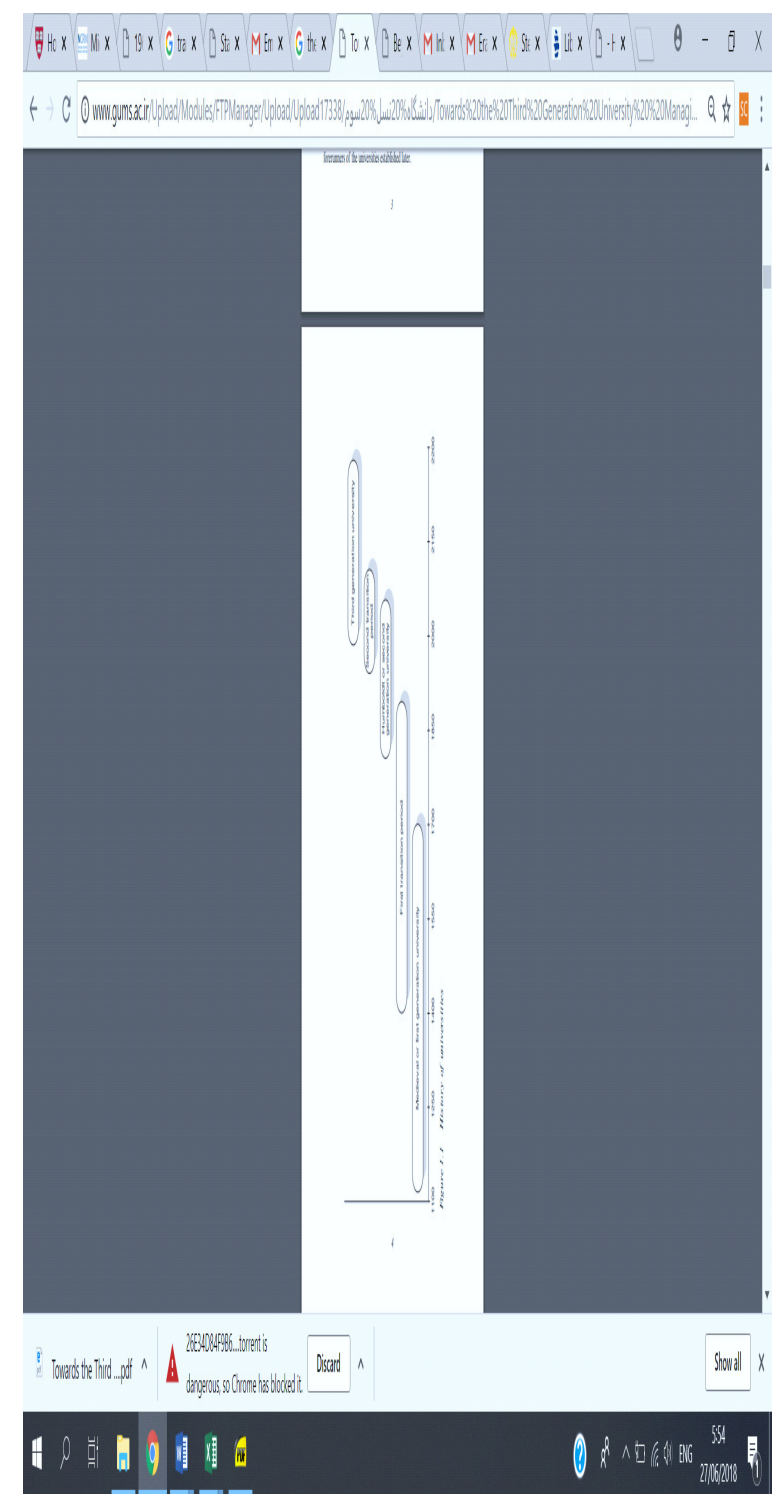

Image 1 - History of University Transition

Source: (Wissema, 2009, page 4)

Afterwards, the second generation of the university is called as Humboldt University, which functions are not only to produce useful knowledge that can be directly used, but also to show how the knowledge is invented, to stimulate scientific idea in the students' mind, to encourage them to calculate the fundamentals of scientific law in all their thoughts (Wissema, 2009). Wissema (2009) further explained about the third generation university (3GU), which has the following characteristics:
- Exploitation of knowledge becomes the main purpose of the third university, as an institution that is perceived as a place to produce new entrepreneurial activities, in addition to undertaking traditional tasks such as research and education.

- 3GU operates in an internationally competitive market. They are active to compete to earn the best academics, students, and research contract from industry.

- $3 \mathrm{GU}$ is a university network that collaborates with industry, private research institution, investor, consultant, and other universities through the collection of knowledge that they possess.

- Most of the researches are interdisciplinary, and $3 \mathrm{GU}$ embraces the concept of "consilience" and creativity as the pushing factor that is equally important with rational scientific method.

- $3 \mathrm{Gu}$ is a multicultural organization that is composed of various staffs and students.

- It is cosmopolitant, and the university operates within international arrangement and uses English for all subjects.

- $3 \mathrm{GU}$ is independent and less reliant to government regulation.

Wissema (2009) attempted to summarize the main traits of transition from respectively first, second, and third generation of higher education in the following table 1 : 
Table 1. Main Traits of the Three Generations of University

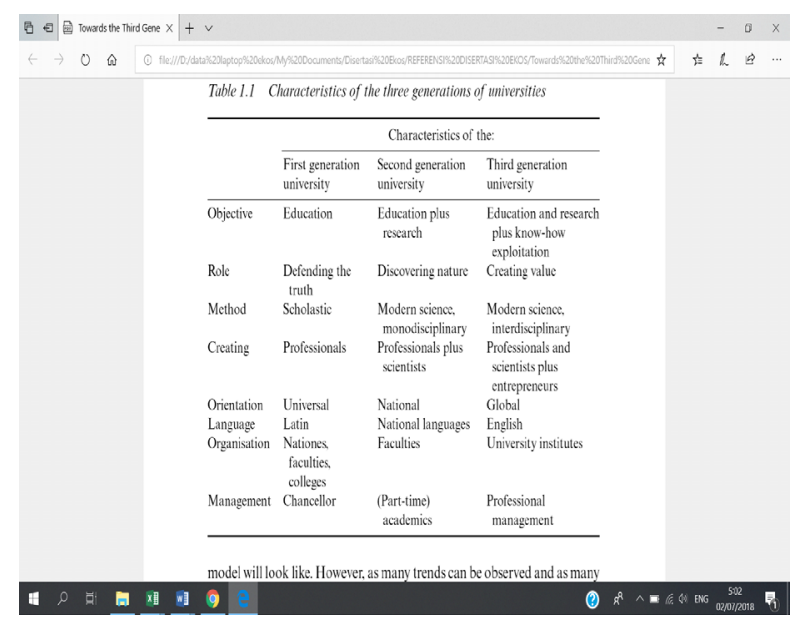

Source: (Wissema, 2009, page 23)

\section{Literature Review and Discussion \\ Definition of Entrepreneurial University}

The concept of Entrepreneurial University was introduced for the first time by Etzkowitz (1983), which describes when a university is seeking new funding such as from patent, research funded by contract, as well as building partnership with private company. In modernization era, in which universities become the center of economic knowledge, entrepreneurship-oriented universities are perceived as the central power that promote innovation, creativity, and economic growth (Audretsch, 1995; Audretsch, et al., 2006). Etzkowitz (2003) suggested that just like traditional process undertaken by each university by training their students to be competitive in life after campus, Entrepreneurial University is a natural incubator, as it provides support structure for teachers and students to start a new business.

The concept of entrepreneurial university is the most appropriate to assist an institution to determine its strategy direction, which focuses on academic goal, by changing knowledge produced in university into a product with economic value and social utility (Clark, 1998). Not only does it have to incorporate entrepreneurial education, but also determine how start-ups are supported in the university. Universities also need to partner with organizations and strive for the vision on how the existing infrastructure can be utilized to maintain entrepreneurial efforts (Fayolle, Redford, 2014).

OECD (2009) in its white paper release on entrepreneurial university framework wrote that it is difficult to find one fixed definition. Table 2 in the following elaborates on various definitions of Entrepreneurial University.

Table 2 - Definitions of Entrepreneurial University

\begin{tabular}{|c|c|c|}
\hline Year & Author & Definition \\
\hline 1983 & Etzkowitz & $\begin{array}{l}\text { University that is seeking } \\
\text { new funding such as from } \\
\text { patent, research funded by } \\
\text { contract, as well as building } \\
\text { partnership with private } \\
\text { company. }\end{array}$ \\
\hline 1995 & $\begin{array}{l}\text { Chrisman, Hynes } \\
\text { and Fraser }\end{array}$ & $\begin{array}{l}\text { An entrepreneurship-orient- } \\
\text { ed university that involves } \\
\text { the creation of new business } \\
\text { by its professors, techni- } \\
\text { cians, or students. }\end{array}$ \\
\hline 1995 & Dill & $\begin{array}{l}\text { Formal measures under- } \\
\text { taken by university through } \\
\text { technology transfer to utilize } \\
\text { research into a commercial } \\
\text { business. }\end{array}$ \\
\hline 1998 & Clark & $\begin{array}{l}\text { Attempts to innovate in how } \\
\text { to run a business, create } \\
\text { shift of substantial orga- } \\
\text { nizational characters, and } \\
\text { become a university that is } \\
\text { an important actor in their } \\
\text { own terms. }\end{array}$ \\
\hline 1998 & Ropke & $\begin{array}{l}\text { It means three things: the } \\
\text { university itself, members } \\
\text { of university - faculty, and } \\
\text { university's interaction with } \\
\text { its environment. }\end{array}$ \\
\hline 1999 & Subotsky & $\begin{array}{l}\text { A university that is featured } \\
\text { with a closer partnership } \\
\text { between university and busi- } \\
\text { ness sector, through wider } \\
\text { faculty's responsibility to ac- } \\
\text { cess external funding source } \\
\text { and managerial ethics in } \\
\text { institutional governance, } \\
\text { leadership, and planning. }\end{array}$ \\
\hline
\end{tabular}




\begin{tabular}{|c|c|c|}
\hline 2002 & Kirby & $\begin{array}{l}\text { A university that has the } \\
\text { capacity to innovate, identi- } \\
\text { fy, and create opportunity, } \\
\text { work in team, take risk, and } \\
\text { respond to challenges. }\end{array}$ \\
\hline 2003 & Etkowitz & $\begin{array}{l}\text { A university that functions } \\
\text { as the natural incubator that } \\
\text { provides supporting struc- } \\
\text { ture for its lecturers and stu- } \\
\text { dents to start a new business } \\
\text { intellectually, commercially, } \\
\text { and combination of both. }\end{array}$ \\
\hline 2003 & Williams & $\begin{array}{l}\text { No more than a service } \\
\text { vendor to the knowledge } \\
\text { industry. }\end{array}$ \\
\hline 2003 & $\begin{array}{l}\text { Jacob, M, } \\
\text { Lundqvist and } \\
\text { Hellsmark, }\end{array}$ & $\begin{array}{l}\text { It is based on commercial- } \\
\text { ization (higher education } \\
\text { course, consultation and } \\
\text { coaching services) and com- } \\
\text { modification (patent right, } \\
\text { licensing, or start-up owned } \\
\text { by students). }\end{array}$ \\
\hline 2006 & $\begin{array}{l}\text { Guerrero-Ca- } \\
\text { no, Kirby, and } \\
\text { Urbano }\end{array}$ & $\begin{array}{l}\text { Entrepreneurial University } \\
\text { is defined as a universi- } \\
\text { ty that has the ability to } \\
\text { innovate, identify and create } \\
\text { opportunity, work in a team, } \\
\text { take risk, and respond to } \\
\text { challenges (Kirby, 2002a), } \\
\text { and naturally, attempts to } \\
\text { create major changes in the } \\
\text { organization's characteris- } \\
\text { tics so as to achieve a more } \\
\text { promising posture for its fu- } \\
\text { ture (Clark, 1998). In other } \\
\text { words, it is a natural incuba- } \\
\text { tor that provides supporting } \\
\text { structure for its lecturers } \\
\text { and students to start a new } \\
\text { business intellectually, com- } \\
\text { mercially, and combination } \\
\text { of both (Etzkowitz, 2003). }\end{array}$ \\
\hline
\end{tabular}
(2018)

The numerous definitions are strongly relevant with the university's process, goal, measures, and capability to obtain new funding source. Another perspective was offered by Thorpe and Goldstein (2010), who perceived entrepreneurship as a way of thinking that can increase the impacts of innovation. So to succeed in a university setting, entrepreneurship must be clearly defined as a necessary ingredient for innovation, a particular approach to solving problems, and a complement to-not a substitute for-the critical methods that are fundamental to the liberal arts and sciences."

"Entrepreneurship, then, is not a subject or a discipline, but a practice or a way of thinking that can increase the impact of innovation...

So to succeed in a university setting, entrepreneurship must be clearly defined as a necessary ingredient for innovation, a particular approach to solving problems, and a complement to-not a substitute for-the critical methods that are fundamental to the liberal arts and sciences."

(Thorpe and Goldstein, 2010, h.7)

It can be concluded that an entrepreneurial university is one that attempts to optimize its resources, build entrepreneurial and innovative characteristics for its entire civitas academia (lecturers, students, and staffs), in creating opportunity and new efforts to respond to future challenges.

\section{Challenges of Entrepreneurial} University

According to Gibb (2013, in Coyle, Gibb and Haskins, 2013), challenges that emerge in the term 'entrepreneurial university' is the concept of entrepreneurship for universities, i.e. entrepreneurial university is associated with the efforts to undertake commercialization of various intellectual properties which are the results of various innovations, patents, and researches conducted bylecturers throughtransfer of technology, incubator, and science parks. Whereas, a wider concerpt can also be implemented. Gibb (2013) expressed the necessity to operationalize the concept of "enterprise" and "entrepreneur".

Gibb (2013) also highlighted the concept of enterprise that focuses on development of 'entrepreneurs and entrepreneurial mindset'. An entrepreneur is a set of private skills, attributes, capacity of behavior and motivation that can be used in the 
social, professional, recreational, and other contexts. The stand-out characteristics of an entrepreneur are: intuitive decision making, capacity to make something happen independently, ability to build network, take initiative, identification of opportunity, creative problem solving, strategic thinking, and self-efficacy. Whereas, entrepreneurial mindset is an individual's ability to solve his/her external environment which is unpredictable and the associated entrepreneurial means in doing, thinking, feeling, communicating, arranging, and learning.

Meanwhile, the concept of entrepreneur focuses on the application of individual's business skills, attributes, and mindset in the context of forming a new business or initiative in any forms, development of existing business or initiative, and designing a business organization (Gibb, 2013, in Coyle, Gibb and Haskins, 2013).

Referring to Fayolle and Redford (2014), there are 2 (two) challenges on how a university transforms from traditional pattern, which in practice only implements the Tri Dharma (three university duties), toward an entrepreneurial university. First, universities have to pay attention on the coherence between themselves and their environment. Universities have to avoid the 'ivory tower' attitude, by taking into account thoroughly the speciality of their context with the need of their stakeholders. The second condition is associated with the need to change university's culture, in form of values, attitude, and promote and disseminate entrepreneurship culture and values in each university.

At a more practical level, the research conducted by Ahmad, Halim, and Ramayah (2016) also explained about the challenges and barriers that occur in building an entrepreneurial university, which cover:

- Role Overload for Academics

Academics refuse to execute various new activities using the pretext that they are already preoccupied with their teaching routines and existing researches. With new role as academic entrepreneur, dilemma ensues as to how the academics can accomplish balance between maximizing contribution for teaching, knowledge development (research), and generating income (entrepreneur).

- Emergence of assumption of deviation from the original purpose of university's roles

Some academics also hold the perspective that entrepreneurial university has "crossed the line" from its real function as university. University might play role as a support to business environment, but not as a business actor.

...."role of the university is not to "do business" but to "support business"”

(Ahmad, et al., 2016, h. 527)

- Bad impacts for lecturers' career advancement

Another resistance is associated with lecturer career development, in which research and publication are treated as the main factors that influence academics' career, rather than their task to become academic entrepreneur, who act to produce start-ups which might generate additional income for the university. This has made lecturers' intention to innovate and commercialize becomes less than their need to launch scientific publication.

- The absence of entrepreneurial culture and mindset in university

The low entrepreneurial culture in universities made research quality as the preliminary input in form of patent/prototype that will get 
into industry unconnected with the market need (not market-driven). In addition, the lack of market knowledge also poses another barrier in the commercialization process of the research results.

- Unattractive incentive mechanism

Academics assume that incentive mechanism during the course of research and innovation which aims to promote creation of start-ups and their commercialization fail to offer any clear reward mechanism.

- Absence of entrepreneurial model and expert

The lack of success example in the process of creating start-ups by academics, as well as absence of assistance in commercialization process conducted at universities.

- Lack of network toward industry

One of the barriers that appears during commercialization, which is the difficult access toward market/ industry, becomes a crucial problem for entrepreneurs from universities.

- Lack of trust between industry and university

The involvement, commitment, and trust between industry and academics are considered as a real challenge to push forward research results from laboratory into commercialization. The absence of trust between both parties have hindered the initial steps toward successful commercialization.

Transformation of Entrepreneurial University

It is inevitable that organizational transformation will always go through several steps or trajectories in its change process. So is the case with universities that transform themselves from traditional paradigm into Entrepreneurial University. Several universities currently are transforming into an ecosystem that utilizes knowledge to support entrepreneurship as an effort to create knowledge-based economy (Etkowitz, 2004; Etkowitz, et al., 2008; Guerrero, et al., 2018).

The research conducted by Cohen, Nelson, and Walsh (2002) and Guerrero and Urbano (2017) (in Guerrero et al., 2018) concluded that there are 2 (two) important roles of universities in promoting entrepreneurship. First, universities have transformed into an environment that intensifies knowledge to support entrepreneurship through significant roles of combination of human resources and aspiration in the number of start-ups made by their graduates. Second, there is influence between university support mechanism (incubator and research park) with graduates that initiate start-ups through provision of access to knowledge, technology, and resources needed to create and develop the start-ups.

Philpott, et al. (2010) also explained that various activities conducted by universities that still have traditional paradigm, and those which are done by universities who have entrepreneurial paradigm (see Image 2). Referring to Philpott, et al. (2010) and Ahmad, et al. (2017), various activities conducted by universities, such as producing graduates with excellent qualification, academic publication, obtaining grant, providing consultation, implementation of various trainings for industry, research contract, establishment of university's subsidiary/ business unit, as well as construction of technology park, which is an area managed by specialists, aim to increase the community's wealth by promoting the culture of business innovation and competitiveness and knowledge-based institution. 


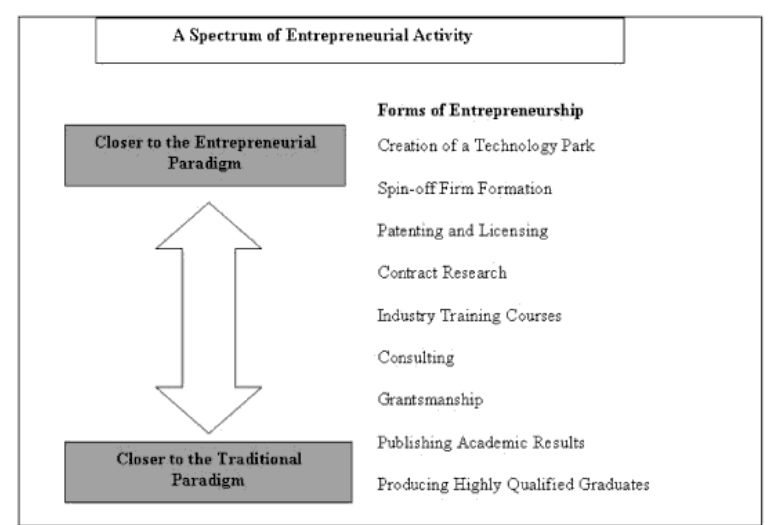

Figure 2 - Range of Activities of Traditional Paradigm Universities with Entrepreneurial Universities

Source: Philpott, et al. (2011)

Referring to UNESCO, science park a.k.a. technopark may stimulate and manage the flow of information and knowledge as well as technology between universities, R\&D institution, company, and market. This facilitates the creation and growth of innovationbased company through incubation and spin-off processes, and provides other added value services altogether with high quality rooms and facilities.

Leslie and Slaughter (1997, in Bonaccorsi and Daraio, 2007), also attempts to explain the transformation of entrepreneurial university, from soft entrepreneurial, which is a condition in which universities seeking funding from various parties (government, alumni, industry, and philantrophy) for class and research purposes through media liaison offices; toward hard entrepreneurial, which is a condition in which universities have strategy to establish a company through spin-off, business incubator and science park which are initiated through university-industry collaboration.

$$
\text { Subsequently, Clark }
$$
also explained the 3 (three) phases of entrepreneurial university transformation. The first phase is when universities initiate their institutional direction and priority through negotiation process with various parties that have the resources. The second phase is when universities start to play active role in commercialization process from intellectual properties which are produced by their lecturers, staffs, and students. The third phase is when universities proactively develop their role at regional level.

Similar opinion was also expressed by De Zilwa (2005), who stated that the transformation of entrepreneurial university are taken through 3 (three) steps.

Figure 3 - Transformation of Entrepreneurial University

Source: De Zilwa (2005), figure was processed by researcher (2018)

At non-entrepreneurial step, universities do not conduct any business activities, since their budget is fully subsidized by the government. Even if there is, it is only in form of additional business, such as canteen, and not in form of activities of establishing core business. At semi-entrepreneurial step, universities start to open new and innovative research centers and academic units in order to earn more income, although they not necessarily can generate profit. The third step, which is pure entrepreneurial, is when universities start to actively seek business profit by establishing subsidiary through spin-off and joint ventures with industry through commercialization of research results and patent.

According to Etzkowitz's research (2004), evolution of universities from traditional paradigm and research universities toward entrepreneurial universities go through 4 (four) steps, covering:

- Establishment of research group or quasi-firm, which is the establishment of research group systematically to achieve strategic targets, as its first 
step.

- The next step is liaison office, in which universities attempt to establish a special activity unit that handles various consultations and researches with external parties (industry, government and community) as well as contracts of economic values.

- The third step is when universities establish a technology transfer office, which is a unit that handles intellectual rights, patents, and licenses management produced by their lecturers and researchers.

The last step is incubator, in which universities perform governance and coaching to commercialize various results of the previous steps through establishment of enterprise/business that is under its management.

The paradigm of entrepreneurial university creates opportunity for university to become more independent, through the use of commercialization of various intellectual property rights produced from their researches and technology (Etzkowitz, 1998).

Further thought on this matter was mentioned by Scharmer (2018), who argued that to create a 21st century university, we must not only emphasize on the class teaching and research, but also create an ecosystem that collaborates study, research and renewal of civilization through most updated learning and innovation methods. So is the case with the condition of higher education in Indonesia. In the agenda of National Working Meeting of the Ministry of Research, Technology and Higher Education, Mohamad Nasir also expressed that campuses are expected to developamoreinnovativelearningsystem in universities such as by adjusting their curricula, as well as enhancing students' ability in Information Technology (IT), Operational Technology (OT), Internet of Things (IoT), and Big Data Analytic, by integrating physical, digital, and human objects to produce competitive and skilled graduates particularly in data literacy, technological literacy, and human literacy, as well as innovation breakthroughs and strengthening of innovation system to increase industry productivity and technology-based start-up companies (ristekdikti.go.id, 2018). As consequence, universities currently are transforming into an ecosystem that utilizes knowledge to support entrepreneurship (Guerrero, et al., 2018).

In managing universities in Indonesia, the government, through the Ministry of Research, Technology and Higher Education (MRTHE), refers to Law Number 12 of 2012 on Higher Education. Higher Education is defined as the level of education following middle education which comprises diploma, undergraduate program, magister program, doctorate program, and professional program, as well as specialist program, which are administered by universities based upon Indonesian culture. Subsequently, the government divided state university's status by referring to Law No.12 of 2012 Article 65 and Government Regulation No. 4 of 2014 Article 27, which divide management of State University into (a) State University with state financial management which generally is known as Work Unit State University (PTN Satker) or Non-Tax State Income (PNBP) State University (PTN PNBP); (b) State University with financial management pattern of public service agency or PTN-BLU; (c) State University as an autonomous/public agency or PTN-BH, namely: University.

Currently, there are 12 state universities that are divided into 3 (three) types of management, with details are as follows: (1) 11 PTN-BHs which were determined by Government Regulation; 
(b) 24 PTN-BLU which were determined b Minister of Finance's Decree; (c) 86 PTN Satker, including 35 new PTNs which staffing is governed in Presidential Regulation No.10 of 2016, by referring to Law No. 5 of 2014 on State Civil Apparatus and 3 Community Academies. The designation of PTN-BH is conducted with Government Regulation, while PTNBLU is conducted through Minister of Finance's Decree, upon suggestion from the Minister of Research \& Technology and Higher Education (FItri, 2016).

In the preliminary interview with a senior functional staff of the Ministry of Research, Technology and Higher Education (MRTHE), Iskandar, it was mentioned that there is a phenomenon where the government attempts to make PTN-BH into an independent PTN, which means the state university can optimize all of its assets both physical and intellectual (research results, patent, prototype and alike) to be its source of income outside of the allocation from the national government. What is expected from the government toward PTNBHs is that by using their authority to establish a business, downstreaming or commercialization of research results and technology will take place in collaboration with industry, so that the PTN-BHs can increase their income from other sources than Education Fund (Non-BP Income). Similar idea was also expressed by the Secretary General of the MRTHE, Ainun Naim, who stated that PTN-BH universities are expected to build and advance civilization, develop, and be innovative (ristekdikti.go.id, 2017).

Initially, there were 4 (four) PTNBHs which were the result of status transformation from BHMN (Stateowned Enterprise), namely Universitas Indonesia (UI), Institut Teknologi Bandung (ITB), Universitas Gajah Mada (UGM), and Institut Pertanian
Bogor (IPB), which were designated through a Presidential Regulation that was determined on 14 October 2013. Afterwards in 2014, the government determined 3 (three) other state universities to become PTN-BH, namely: Universitas Airlangga, Universitas Sumatera Utara and Universitas Pendidikan Indonesia. Then in 22 July 2015, 4 (four) more state universities were designated to become PTN-BH, namely: Institut Teknologi Sepuluh Nopember, Universitas Hasanuddin, Universitas Diponegoro, and Universitas Padjajaran. Table 1 shows the list of PTNBH in Indonesia.

Table 1.1. List of PTNBH in Indonesia

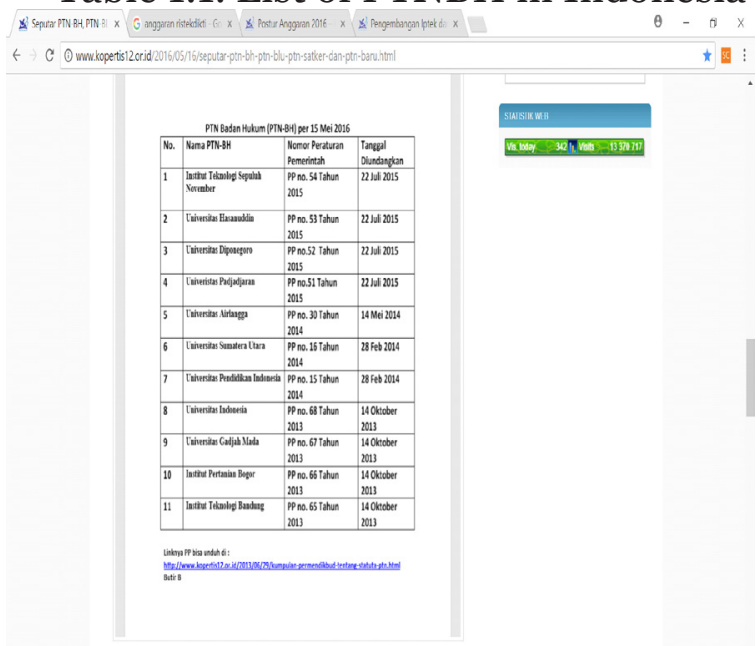

Source: Fitri (2016)

In accordance with the prevailing policy, Law Number 12 of 2012, article 65, PTNBH has authorities, including to establish an enterprise and develop eternal fund and right to manage the fund in independent, transparent, and accountable manners. The authority often raises concern from many that it would become a first step towards commercialization of higher education, by which PTNBH will unilaterally raise the tuition fee. This happened because when a state university (PTN) has the legal entity (autonomous) status, and therefore it has the autonomy both 
academic and non-academic wise, the education cost is not merely delegated to state, but also to students or external parties and investors (Adriennawati, 2016; Yonvitner, 2017).

However, on one hand, the government also iterated that the status as PTNBH does not necessarily make the state university commercial. The government, through the Minister of Research, Technology, and Higher Education (RTHE), Mohamad Nasir, reiterated that Autonomous State University (PTNBH) is not allowed to increase the tuition fee (UKT) when receiving new students of 2017/2018 class. The Minister of RTHE argued that PTNBH status doesn't necessarily mean that the campus can commercialize higher education using pretext of developing world class educational facilities. Furthermore, in order to prevent any misunderstanding from the society, he further explained that PTNBH is not any kind of privatization or commercialization (Seftiawan, 2017; Ristekdikti.go.id, 2017).

To avoid any privatization or commercialization of higher education by PTNBH, the government gave funding in form of BPPTN-BH (Funding for Autonomous State University), which previously was known as Operational Assistance for State University (BOPTN). In line with the mandate of Law Number 12 of 2012 on Higher Education Article 83 paragraph (1), the "government provides higher education fund that is allocated in the National Budgetary Income and Expenditure".

Afterwards, also in the same law, article 89 (paragraph 2) also stated that the Higher Education Fund for state university with legal entity (PTNBH) is given in form of subsidy and/or other forms in accordance with the applicable laws and regulations. The funding mechanism for BPPTN-BH is governed in Government Regulation Number 26 of 2015 Article 5 and 6, which states that BPPTN-BH funding covers subsidy for: operational cost, non-civil servant lecturer cost, non-civil servant education cost, investment cost, and development cost. The amount of funding for BPPTN-BH is determined based on the suggestion of each PTN-BH, on the basis of (1) performance target; (2) operational cost need, lecturer cost, educational staff cost, investment cost, and development cost; (3) calculation of operational cost unit of university and acceptance plan of PTN-BH.

Throughout the course of 2015-2017, the budget for higher education has plummeted significantly. The decrease of BPPTN subsidy is indicated by the amount of education budget allocation in the Ministry of Research, Technology and Higher Education over the past 3 years, just like described in the following graph:

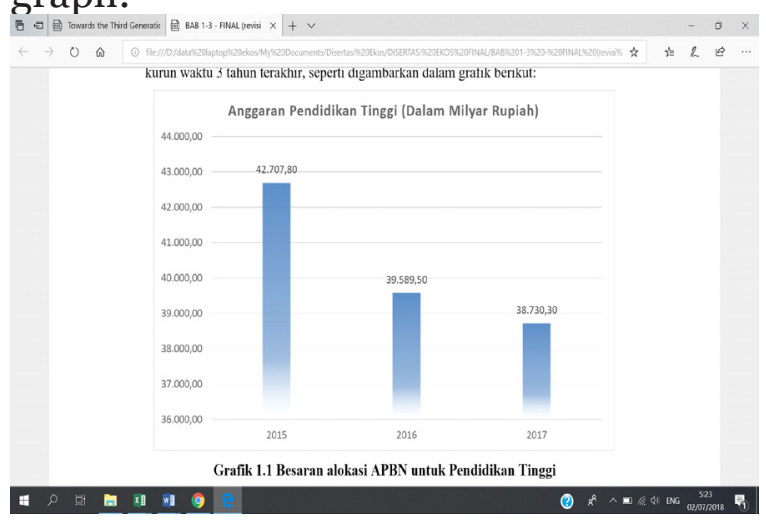

Graph 1 - Amount of National Budget Allocation for Higher Education

Source: anggaran.depkeu.go.id (2017), data was processed by researcher (2018)

Graph 1 shows that posture-wise, the national education budget ceiling over the past 3 years has plummeted significantly. Based on the data from the Directorate General of Budget of the Ministry of Finance, Republic of Indonesia, the budget of Higher Education decreased from the previously 42.707 trillion rupiahs in 2015 , to 38.730 trillion rupiah 
in 2017, which was an IDR 3.977trillion or 9.31\% decrease. The decrease of national education budget was also influenced by the decrease of subsidy for BOPTN/ BPPTN-BH. In 2015, the MRTHE allocated IDR 4.5 trillion for BOPTN, yet in 2016, the number decreased to only IDR 3.763 trillion (Zubaidah, 2016).

In Indonesian context, most (almost all) of the universities in the country highly depend on government funding and students tuition, and thus with such a system and very limited resources, it is simply too difficult for universities in Indonesia to develop and compete with universities from abroad (Oey-Gardiner, 2017).

The decrease of BOPTN/BPPTN subsidy is considered to be reducing state universities' performance. Rector of UI, Prof. Muhammad Anis suggested that the decrease of BOPTN will affect the quality of implementation of quality Tri Dharma (three university duties) along with the increasing operational cost, while the lack of funding cannot be borne fully by students (mediaindonesia.com, 2015). The income of state universities from the National Budget which is disbursed through the Operational Assistance for University (BOPTN) originally aims to cover the lack of operational fund due to the decision not to increase the tuition fee and use of single tuition fee (UKT) (RKA UI, 2015).

The RKAT UI report of 2015 shows that the real income received by UI became a problem. For example, the amount of real income of UI in 2015 consisted of 900.618 billion rupiahs from education fund, 352.034 from non-education fund, and 234.365 billion from BOPTN subsidy (see graph 2).

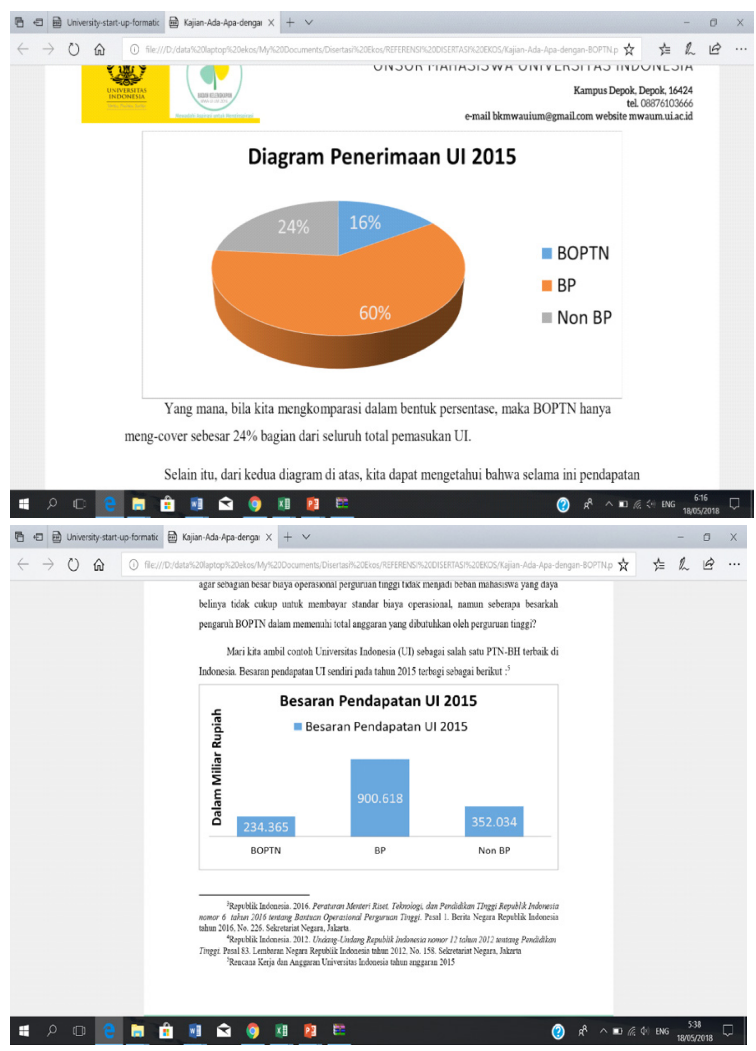

Graph 2 - Real Income of UI in 2015

Source: Arif (2016)

The uneven composition of income from education fund, non-education fund and subsidy for BOPTN (currently named BPPTN-BH) reflects that UI still relies on education fund from students, whereas, percentage-wise, UI income from student education income constitutes $60 \%$, BOPTN subsidy $16 \%$, and non-education fund constitutes $24 \%$. Arif (2016) released a study that inquires the government's role in developing higher education in Indonesia through the minimum BOPTN subsidy.

The Minister of Research, Technology, and Higher Education Regulation Number 6 of 2016 on University Operational Assistance, Article 4 sets forth that the BOPTN transfer refers to the following criteria: (1) the education fund needed by diploma program and undergraduate program students, (2) Amount of non-tax state income which originates from diploma and 
undergraduate program students, (3) university's performance, and (4) Number of diploma and undergraduate program students. The formula to calculate BOPTN for each university is as follows:

The Single Tution Cost (BKT) is the total operational cost needed by a student per semester to undergo study in a program in a state university, while Single Tuition Fee (UKT) is a part of BKT which is borne by every student in accordance with his/her economic capacity. If we refer to graph 1.3, all this time, the UKT (a.k.a. BP income) has bigger amount from BOPTN to meet the BKT, which means that the role of every student in funding higher education is higher than that of the state (Arif, 2016).

Other information obtained from the initial interview with the Head of Sub-Directorate of Budget, University of Indonesia, Selo Sukardi, S.Si., the problem is the steadily increasing rate of PTNBH operational cost, while the government allocation for BPPTN-BH is relatively stagnant, while income from non-education fund does not significantly increase. The reason is confirmed with the data on budget of the past 3 (three) years. According to the data from the Planning and Budgeting Office of the University of Indonesia, the work plan for UI's expenditure budget in for 2015-2017 increased, while the BPPTN$\mathrm{BH}$ subsidy tends to be stagnant, making the percentage ratio decline (see Graph 3 and 4).

RKA Penerimaan dan Pengeluaran UI 2015-2017

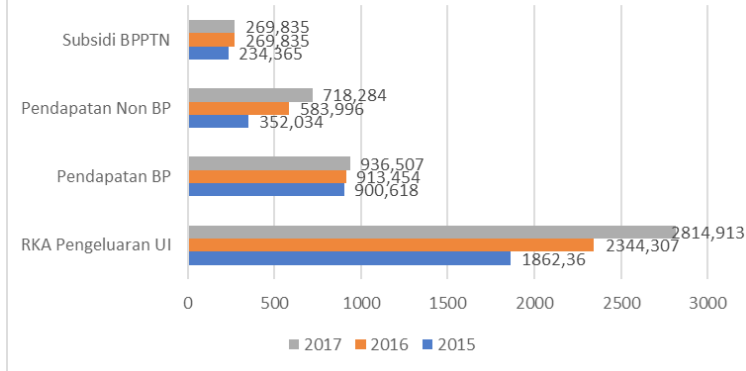

Graph 3 - UI Budgetary Posture of 2015-2017 (in billion rupiahs)

Source: RKA UI of 2015, 2016, 2017, data was processed by researcher (2018)

According to RKAT UI's data, the work plan and expenditure budget of the UI increased from 2015-2017. In 2015, the university's expenditure plan reached 1.862 trillion rupiahs, while the income from education cost was 900.618 billion rupiahs, while that from non-education cost was 352.034 billion rupiahs. In the same year, UI received BPPTN-BH subsidy from the government at the amount of 234.365 billion rupiahs.

Afterwards in 2016, the RKAT expenditure amount of UI increased by almost $25.4 \%$ (or 473 billion rupiahs) from the previous year, which was 2.336 trillion rupiahs. The increase of the expenditure budget was not followed by any significant increase of income budget source. In 2016, the education fund income only increased by $14.25 \%$ or 13 billion rupiahs, while that of noneducation fund reached 583.996 billion rupiahs or increased by $65.89 \%$. In 2016 , it was estimated that UI would receive non-BP income from all of its venture activities, be it from PAU, faculty, and agency. Some part of the Non-BP income was managed and obtained through PAU Work Unit with a total income value of IDR 235,959,791,486. Non BP PAU Income originated from, among others, new student enrollment, graduation, UI Expo, PUPT (Dikti) and Ministry of RTHE grant, Makara Hotel, etc.

In 2017, the RKAT Expenditure of UI increased again by 478 billion rupiahs to 2.814 trillion rupiahs, while the income from education fund increased only by 23 billion rupiahs from 2016, which means a 936.5 billion rupiahs, and non$\mathrm{BP}$ income increased by $23 \%$ to 718.28 billion. However, BPPTN-BH subsidy remained the same with that of 2016, 
namely 269.835 billion rupiahs.

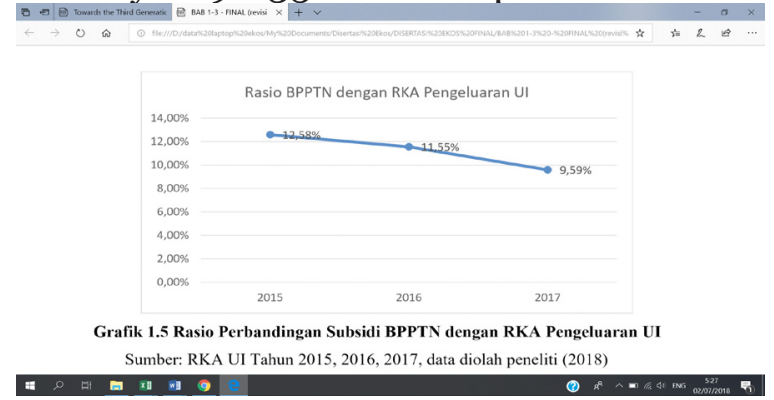

Graph 4 - Ratio of Comparison between BPPTN Subsidy with RKA Expenditure of UI

Source: RKA UI of 2015, 2016, 2017, data was processed by researcher (2018)

Observed from the comparison ratio of BPPTN-BH subsidy with RKA Expenditure of UI, the percentage of allocated BPPTN-BH in 2015 was 12.58\%, and the number steadily decreased in 2017 at the rate of $9.59 \%$. This means that the gap of subsidy amount does not correlate with the cost of implementing Tri Dharma by UI, which number keeps increasing.

Similar thing also happens in Universitas Gadjah Mada (UGM). According to the university's rector, Prof. Dwikorita Karnawati, the amount of BPPTN-BH subsidy cannot cover the operational cost of classes (Febriarni, 2016). According to the report of Annual Work Plan and Budget (RKAT) of UGM of 2015-2017, the income from BPPTN$\mathrm{BH}$ subsidy decreased during the period, although its expenditure increased. Hence, observed from ratio between its RKAT Expenditure with BPPTN-BH income, the gap is increasing, and UGM has to find another source of funding through cooperation with other parties (Febriarni, 2016).

RKA Penerimaan dan Pengeluaran UGM 2015-2017

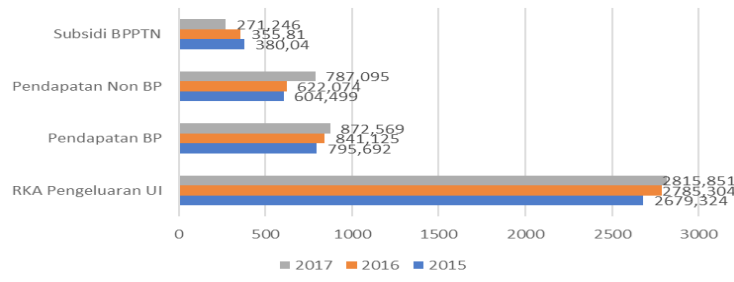

Graph 5 - UGM Budgetary Posture of 2015-2017 (in billion rupiahs)

Source: RKAT UGM of 2015, 2016, 2017 , data was processed by researcher (2018)

From the report of RKAT UGM of 2015-2017, it was found out that the university's budgetary posture of 2015 reached 2.679 trillion rupiahs, while its allocation of income from education fund was 795.692 billion rupiahs, and that from non-education fund was 604.499 billion rupiahs. UGM received BPPTN$\mathrm{BH}$ subsidy from the government that amounted 380.04 billion rupiahs or around $14.18 \%$ of the total budget.

In addition, in 2016, the university's RKAT Expenditure increased by 105.98 billion rupiahs, making it a total of 2.785 trillion rupiahs. This was also followed by an increase in education fund income to 841.125 billion rupiahs, and non-education cost amounting 622.704 billion rupiahs. However, it was the BPPTN-BH subsidy that decreased by 25 billion rupiahs to 355 billion rupiahs.

In budgetary year of 2017, the budget of RKAT Expenditure of UGM increased further to 2.815 trillion, while its allocation of BPPTN-BH decreased to 271 billion rupiahs (see Graph 5). Although the university's education cost income increased slightly by $3.7 \%$ from the previous year, making it 872.569 billion rupiahs. A rather significant increase took place in non-education cost income, which was $26.5 \%$ or around 165 billion rupiahs, to 787.095 billion rupiahs.

Both UI and UGM experienced budget deficit throught the budgetary year of 2015-2017, and in order to cover such a deficit, both universities had to use their budget allocation reserve and remnants from the previous year. Calculated from the ratio of comparison between the amount of BPPTN-BH 
subsidy with the RKA Expenditure of UGM, the percentage seems to further decline (see Graph 6). The percentage of BPPTN subsidy in 2015 was still 14.08\%, and subsequently decreased to $12.77 \%$ in 2016, and further down to $9.63 \%$ in 2017. The figure shows that within the period of 2015-2017, the education cost in UGM was consistently increasing, but it was not matched with increasing subsidy from the government, which forced the university to seek other funding from non-education fund to meet its RKAT needs.

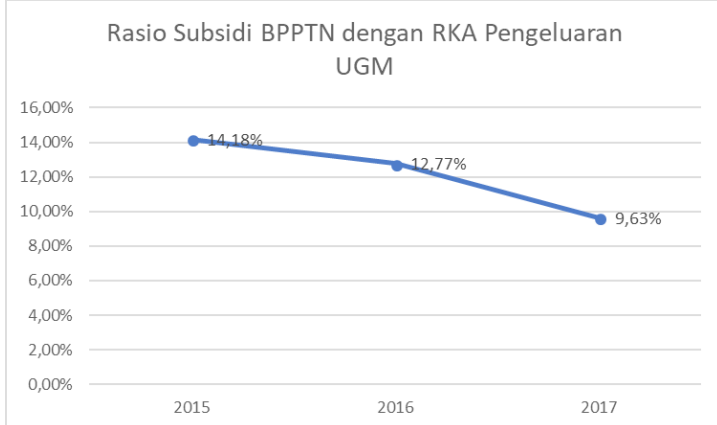

Graph 6 - Ratio of Comparison between BPPTN Subsidy with RKA Expenditure of UGM

Source: RKA UGM of 2015, 2016, 2017, data was processed by researcher (2018)

The increasing discrepancy between operational need of state universities with BOPTN/BPPTN-BH subsidy income must be addressed through institutional strategy at the universities. As mentioned once in a national newspaper, the Minister of Research, Technology, and Higher Education, M. Nasir, stated that universities must restructurize their perspective and transform themselves to an entrepreneurial university (Achdami, 2016). Universities need to change their policy direction, from the previously "Learning and Research University" to "Entrepreneurial University", or balance both policies to achieve both ends (Komara, 2014). Fayolle and Redford (2014) also reiterated that universities need to be more entrepreneurial, change their strategy, structure and practice, change their organizational culture, and help their students and faculty members to develop entrepreneurial mindset and action.

\section{CONCLUSION}

Various changes in external environment have transformed universities into a more complex institution, not only as one that serves as an excellent scientific center and implements the Tri Dharma (three university duties) in education, research, and community service, but also as one that has to innovate to meet its funding needs through various entrepreneurial activities. An adequately clear concept on entrepreneurial university that has been the focus of researches in the past one decade can serve as an entry point for universities to determine their strategic directions in addressing future challenges. As a PTNBH (autonomous university), UI and UGM face challenges to meet their operational cost, as they strive to implement quality Tri Dharma activities. Moving forward, there needs to be a deeper study regarding whether state universities in Indonesia, particularly the PTNBH, which had the autonomous authority to manage their finance, can be categorized as an entrepreneurial university.

\section{REFERENCES}

Achdami, Mulya., 2016, Menristekdikti Dorong Kampus Jadi Entrepreneur University, [online]: www.harnas.com, co/2016/11/11/menristekdiktidorong-kampus-jadi-entrepreneuruniversity

Adriennawati,

Bianca., 2016. Status PTN Badan Hukum Picu Komersialisasi Pendidikan Tinggi, [online]: http:// 
suaramahasiswa.com/status-ptnbadan-hukum-picu-komersialisasipendidikan-tinggi/

Ahmad, Noor Hazlina., Halim, Hasliza Abdul., Ramayah, Thurasamy., 2016. Dilemma on the Entrepreneurial University Ideal: The Prevailing Academic Tensions, Croatian Journal of Education, Vol.18; No.2/2016, pages: 519-543,

Arif, Rizki.2016. AdaApa Dengan BOPTN?, Badan Kelengkapan Majelis Wali Amanat UI Unsur Mahasiswa.

Audretsch, D. B., Lehmann, E., \& Warning, S. 2005. University Spillovers And New Firm Location. Research Policy, 34(7), 113-1122.

Audretsch, David., Lehmann, Erik., Michele, Meoli., Vismara, Silvio., 2016, International Studies in Entrepreneurship, University Evolution, Entrepreneurial Activity and Regional Competitiveness, Springer International Publishing, Switzerland.

Chen, Derek H.C., and Carl J. Dahlman. 2004. Knowledge and Development, a Cross-Section Approach. World Bank Policy Research Working Paper 3366. Washington, DC: World Bank,[online]:https:// openknowledge.worldbank.org/ bitstream/handle/10986/14163/ w p s $3366 \mathrm{k} \mathrm{n} \mathrm{o} \mathrm{w} \mathrm{le} \mathrm{d} \mathrm{g} \mathrm{e} \mathrm{.}$ pdf? sequence $=1$ \&isAllowed $=\mathrm{y}$

Clark, B.R., 2003. Sustaining Change in Universities: Continues in Case Studies and Concepts, Tertiary Education and Management, 9 (2), p.99-116

Coyle, Paul., Gibbs, Allan., Haskins, Gay. 2013, The Entrepreneurial University: From Concept to Action, Entrepreneurial University Leaders Programme, National Centre for Entrepreneurship in Education (NCEE), United Kingdom, online [http://ncee.org.uk/wp-content/
uploads/2014/o6/From-ConceptTo-Action.pdf]

Dahlman, Carl J., and Jean-Eric Aubert. 2001. China and the Knowledge Economy: Seizing the 21st Century. WBI Development Studies. Washington, DC: World Bank. Available: http://info.worldbank. org/etools/docs/library/137742/ ChinaKE.pdf

De Zilwa, D., 2005. Using Entrepreneurial Activities as a Means of Survival: Investigating the Processes Used by Australian Universities: Conceptual Issues and Preliminary Results, Economic Papers, 24 (2), p. 145-163

Delanty, G., 2000. The Governance of Universities. What is the Role of the University in the Knowledge Society?, Canadian Journal of Sociology, 27 (2), p.185-198, [online]: https://www.questia.com/ library/journal/1G1-89435958/thegovernance-of-universities-what-isthe-role-of

Etzkowitz, H. 2004. The evolution of Entreprenerial University, International Journal of Technology and Globalisation, 1 (1), p. 64-77.

Etzkowitz, H. 2003, Research groups as 'quasi-firms': the invention of the entrepreneurial university, Research Policy Volume 32, Issue 1, January 2003,Pages109-121,[online]:https:// www.sciencedirect.com/science/ article/pii/So048733302000094

Etkowitz, dkk. 2008. Pathways To The Entrepreneurial University: Towards A Global Convergence, Science and Public Policy, 35(9), November 2008, pages 681-695

Etzkowitz, H. 2013., Anatomy Of The Entrepreneurial University, Journal of Social Science Information, Volume: 52 issue: 3 , page(s): 486-511, http://journals.sagepub.com/doi/ pdf/10.1177/0539018413485832

Fayolle, Alain., Redford, Dana T. 2014. 
Handbook on the Entrepreneurial University, Edward Elgar Publishing Limited, Cheltenham, UK

Febriarni, Uli., 2016. Kampus Jogja: Bagaimana Mekanisme Perhitungan UKT, solopos.com, [online]: http:// www.solopos.com/2016/05/17/ kam pus -jogja-bagai manamekanisme-penghitunganukt-720173

Fitri. 2016. Seputar PTN-BH, PTN-BLU, PTN-Satker dan PTN-Baru, Kopertis 12, [online]: http://www.kopertis12. or.id/2016/o5/16/seputar-ptn-bhptn-blu-ptn-satker-dan-ptn-baru. html

Gibbs, A Allan., Haskins, Gay. 2013, The University of The Future an Entrepreneurial Stakeholder Learning Organisation?, Handbook of Research in Entrepreneurial EducationVolume4-Entrepreneurial University Handbook, Edward Elgar, online [http://ncee.org.uk/ wpcontent/uploads/2014/06/ ARTICLE_FINAL_FINAL_FINAL_ BOOK_VERSION_UNIVERSITY_ OF_THE_FUTURE.pdf]

Grant, R.M., 2005. Toward a Knowledge Based Theory of The Firm, Strategic Management Journal, Winter Special Issue 17, pp. 109-122.

Guerrero, M., Urbano, D., Cunningham, J. A., \& Gajón, E. 2018. Determinants of graduates' start-ups creation across a multi-campus entrepreneurial university: The case of monterrey institute of technology and higher education. Journal of Small Business Management, 56(1), 150-178. doi:10.1111/jsbm.12366

Huggins R., Jones, M., Upton, S., 2008. Universities As Drivers of KnowledgeBased Regional Development: a Triple Analyses of Wales, International Journal of Innovation and Regional Development, 1 (1), pp 24-47.

Kevin, Philpott., Lawrence, Dooley.,
Caroline, O’Reilly., Gary, Lupton. 2011. The Entrepreneurial University: Examining The Underlying Academic Tensions, Technovation, Volume 31, Issue 4, April 2011, Pages 161-170, [online]: https://ac.els-cdn.com So166497210001331/1-s2.0So166497210001331-main.pdf? tid $=5039 c 37 \mathrm{e}-08 \mathrm{~d} 3-11 \mathrm{e} 8-9 \mathrm{~b} 73-$ oooooaabof27HYPERLINK "https:/ a c . e l s - c d n . c o m / So166497210001331/1 S2.o-So166497210001331-main pdf?_tid=5039c37e-08d3-11e8-9b7 oooooaabof27\&acdnat $=1517656611$ ca4cfe3950041ae57ea720e121 47c7aa"\&HYPERLINK "https:// ac.els-cdn.comSo1664972 10001331/1-S2.O-So166497210 o01331-main.pdf?_tid=50

39 c 37 e - o 8 d $3-11$ e 8 9b7300000aabof2 $7 \&$ acdnat $=1517656611$ ca4cfe39500 41ae57ea720e12147c7aa"acd nat $=1517656611 \_c a 4 c f e 3950041 \mathrm{ae} 57$ ea720e12147c7aa

Klofsten, M., Jones-Evans, D., 2000. Comparing Academic Entrepreneurship in Europe, The Case of Sweden and Ireland, Small Business Economic, 14 (4), p. 299-309 [online]: https://link.springer.com/ article/10.1023/A:1008184601282

Lyall, C. Katherine., Sell, R, Kathleen., 2010. The De Facto Privatization of American Public Higher Education, Change : The Magazine of Higher Learning, Volume 38, Issue 1, [online]: http: //www.tandfonline.com / doi/abs/10.3200/CHNG.38.1.613 ? journalCode $=$ vchn2O

McCaffery, Peter., 2004. The Higher Education Manager's Handbook, Effective Leadership and Management in Universities and Colleges, Second Edition, Routledge Taylor and Francis Group, New York and London 
Mohrman, M., Ma, W., Baker, D., 2008. The Research University in Transition: The Emerging Global Market, Higher Education Policy, 21, pp.5-27

Oey-Gardiner, Mayling., Imam Rahayu, Susanto., Abdullah, Muhammad Amin., Effendi, Sofian., Darma, Yudi., Dartanto, Yudi., Aruan, Cyti Daniela., 2017. ERA DISRUPSI Peluang dan Tantangan Pendidikan Tinggi Indonesia, Akademi Ilmu Pengetahuan Indonesia, Jakarta

OECD. 2009. Universities, Innovation and Entrepreneurship Criteria And Examples Of Good Practice

Scharmer, Otto. 2018. Education is the kindling of a flame: How to reinvent the 21st-century university, [online] : https://www.huffingtonpost.com/ entry/education-is-the-kindlingof-a-flame-how-to-reinvent us_5a4ffec5e4boee59d41coagf

Seftiawan, Dhita, 2017., PTN-BH Dilarang Menaikkan Uang Kuliah Tunggal, Pikiran Rakyat, [online]: http://www.pikiran-rakyat.com/ pendidikan/2017/05/03/ptn-bhdilarang-menaikkan-uang-kuliahtunggal-400377

Sporn, B. 2001. Building Adaptive Universities, Emerging Organizational Forms Based on Experiences European and US Universities, Tertiary Education and Management, 7(2), pp 121-134

Ristekdikti.go.id, 2017., Jangan Maknai Status PTN BH Sebagai Privatisasi atau Komersialisasi, [online]:https:/ ristekdikti go.id/jangan-maknaistatusptnbh-sebagai-privatisasi-ataukomersialisasi/\#QcgLHWk kMGoEV3Ot.99

Thorpe, Holden., Goldstein, Buck., 2010. Engine of Innovation: The Entrepreneurial University in the Twenty-First Century, The university of north carolina press, Chapel Hill

Wissema, Johan G. 2009. Towards
The Third Generation University, Managing University in Transition. Cheltenham (G.B.): E. Elgar.

Yonvitner. 2017, Masih soal Otonomi PTN Badan Hukum, Media Indonesia, [online] : http://www. mediaindonesia.com/news / $\mathrm{read} / 103202 / \mathrm{masih}$-soal-otonomiptn-badan-hukum-1/2017-05-04

Zubaidah, Neneng, 2016., BOPTN Turun, Kampus Harus Cari Tambahan Sendiri, okezone.com, [online]: https://news.okezone.com/ $\mathrm{read} / 2015 / 10 / 19 / 65 / 1234005 /$ boptn-turun-kampus-harus-caritambahan-sendi 